\title{
Investigation of marA Efflux Pump Gene Expression in Ciprofloxacin Resistant Salmonella enteritidis Clinical Strains Using Real-Time PCR
}

\author{
Marjan Khosravani $^{1,2}$, Mohammad Mehdi Soltan Dallal ${ }^{3,4}$, Mehdi Norouzi ${ }^{5,6}$ \\ 1. Ph.D. Department of Microbiology, Fars Science and Research Branch, Islamic Azad University, Fars, Iran. ORCID ID: \\ 0000-0001-5419-4574 \\ 2. Ph.D. Department of Microbiology, Shiraz Branch, Islamic Azad University, Shiraz, Iran. \\ 3. Professor, Divison of Microbiology, Department of Pathobiology, School of Public Health, Tehran University of Medical \\ Science, Tehran, Iran., (Corresponding Author), Tel: +98-21-66402640, Email: msoltandallal@gmail.com, ORCID ID: 0000- \\ 0002-3421-3974 \\ 4. Professor, Food Microbiology Research Center, Tehran University of Medical Science, Tehran, Iran. \\ 5. Associate Professor, Department of Virology, School of Public Health, Tehran University of Medial Science, Tehran, Iran. \\ ORCID ID: 0000-0002-3560-9508 \\ 6. Associate Professor, Research Center for Clinical Virology, Tehran University of Medical Science, Tehran, Iran.
}

\begin{abstract}
Background and Aim: Ciprofloxacin-resistant Salmonella spp. are among the most important causative agents of food-borne infections. The marA efflux pump in this bacterium plays a significant role in the development of drug resistance. The aim of this study was to investigate marA efflux pump gene expression in Ciprofloxacin resistant Salmonella enteritidis clinical strains by Real Time PCR.

Materials and Methods: In this cross-sectional study, strains of Salmonella enteritidis were isolated from clinical specimens of feces using microbial methods. Antibiotic resistance of ciprofloxacin-resistant strains was evaluated by disk diffusion method. The presence of marA efflux pump in the clinical strain of Salmonella enteritidis, intermediate ciprofloxacinresistant, was evaluated using Cart-wheel and PCR. The results of this study were analyzed using SPSS 21 software and one-way ANOVA.

Results: From the 1200 fecal clinical specimens, 60 Salmonella enteritidis were isolated. The highest resistance was related to 9 strains (15\%) and 11 intermediate strains $(18 \%)$ ciprofloxacin. and the least resistance was related to imipenem and chloramphenicol $(100 \%$ sensitive). The results of cartwheel and PCR methods showed that all strains intermediate or resistant to ciprofloxacin had a marA efflux pump. Finally, Real-Time PCR results showed a significant up-regulation of marA gene in $S$. enteritidis strains.
\end{abstract}

Conclusion: According to the results of Real-Time PCR, it seems that the marA efflux pump gene is one of the resistance agents in ciprofloxacin-resistant Salmonella enteritidis.

Keywords: Salmonella enteritidis, Efflux Pump, marA, Real Time PCR

Received: Mar 2, 2019

Accepted: Nov 19, 2019

How to cite the article: Marjan Khosravani, Mohammad Mehdi Soltan Dallal, Mehdi Norouzi. Investigation of marA Efflux Pump Gene Expression in Ciprofloxacin Resistant Salmonella enteritidis Clinical Strains Using Real-Time PCR. SJKU 2020; 25(1): 14-26

Copyright (C) 2018 the Author (s). Published by Kurdistan University of Medical Sciences. This is an open access article distributed under the terms of the Creative Commons Attribution-Non Commercial License 4.0 (CCBYNC), where it is permissible to download, share, remix, transform, and buildup the work provided it is properly cited. The work cannot be used commercially without permission from the journal 


\section{بررسى بيان زن يمٍ افلاكس marA در سويهایىبالينى سالمونلا انتريتيليس مقاوم به Real Time PCR سييروفلوكساسين با استفاده النعان}

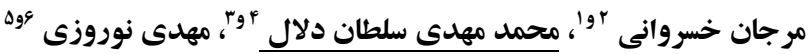

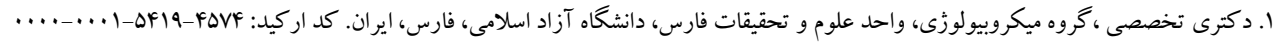

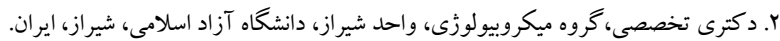

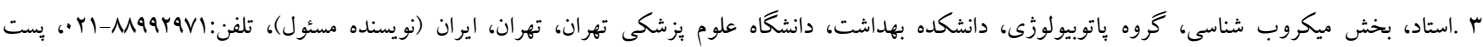

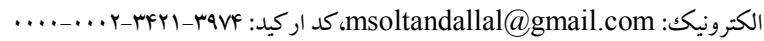

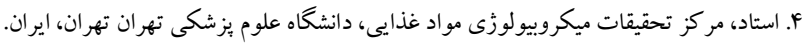

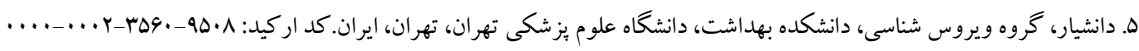

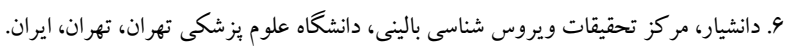

زمينه و هدف: سويههاى مقاوم به سييروفلو كساسين سالمونلا انتريتيديس يكى از مهم ترين عوامل عفونتزاى انتقالدهنده از راه مواد غذايى مىباشند، به طورى كه يمٍٍ افلاكس marA در اين باكترى نقش بسز ايى در ايجاد مقاومت به سيروفلو كساسين دارد.

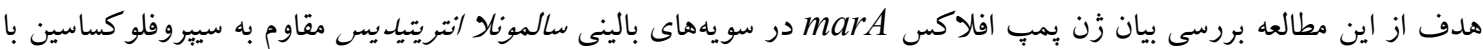
استفاده از روش Real Time PCR است.

مواد و روشها: در اين مطالعه توصيفى-مقطعى، سويههاى سالمونلا انتريتيديس از نمونه بالينى مدفوع با استفاده از روشهاى

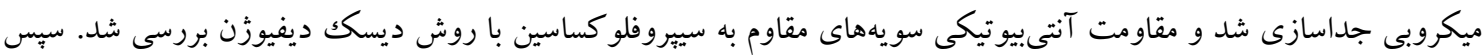

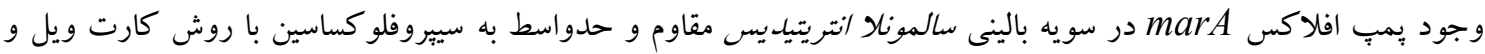
PCR بررسى شد. هم جنين بيان زن marA در سويههاى سالمونلا نتريتيد بس با استفاده از روش

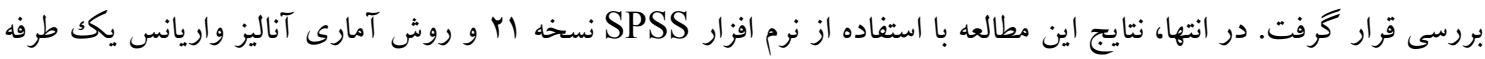
تحليل گرديد. (One-way ANNOVA)

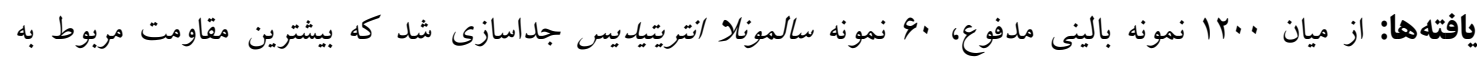

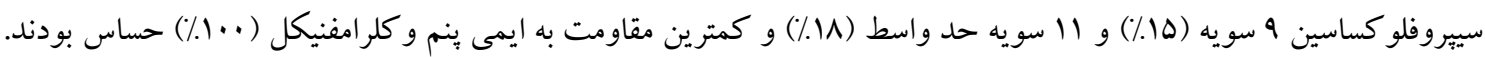

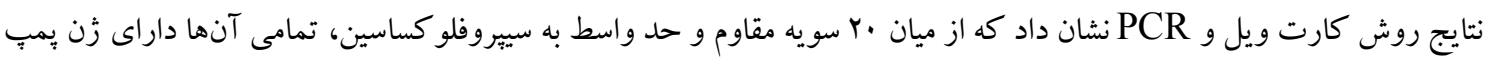

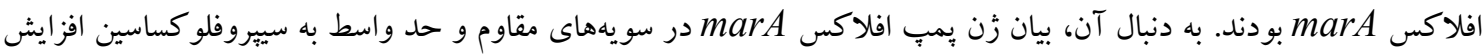
معنى دارى داشته است (ه) (P) نتيجه كيرى: بر بايه نتايج Real Time PCR، زُن بمب افلاكس marA به عنوان يكى از عوامل مقاومت سالمونلا انتريتيديس مقاوم به سييروفلو كساسين است. كلمات كليدى: سالمونلا /نتريتيديس، بمبِ افلاكس، Real Time PCR marA

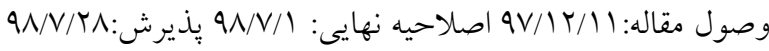


جهت مقاومشدن سويههاى سالمونلا انتريتيديس به آنتى-

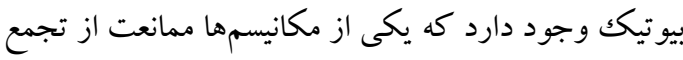
دارو درون سلول به وسيله سيستمهاى افلاكس است. بمبِهاى افلاكس مواد سمى مانند آنتىبيوتيككها را به محيط خارج بمب مى كند و دارا بودن بمبِهاى افلاكس يكى از توانيىهاى اين باكترى براى مقاوم شدن به آنتىبيوتيككها

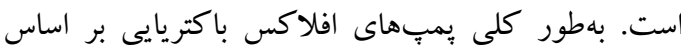

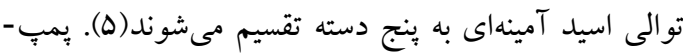
هاى افلاكس از نظر بالينى بهطور مؤثرى در ارتباط با كروههاى يُمٍ افلاكس Nodulation Division Resistance (RND) مىباشند كه با آزادسازى انرزى نيرو محر كه يروتون در

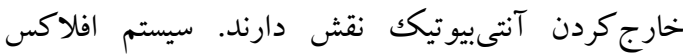
يكى از سيستمهاى مهم افلاكس در باكترى RND

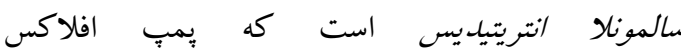
Multiple antibiotic resistance factor )( $\operatorname{mar} A$ ) يكى از يمبهاى مهم اين خانواده است و مطالعات (A نشان مىدهد كه يمب افلاكس marA مىتواند به نواحى

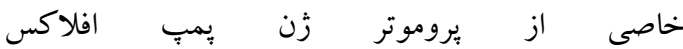
Acriflavin resistance AB (acr $A B)$ مهمترين يمبٍهاى افلاكس سالمونلا است، متصل شده و مىتوانند بيان زن acrAB را افزايش دهد(9). مطالعات نشان مىدهد كه افزايش بيان زن marA مىتواند باعث

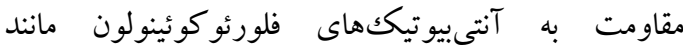
سيروفلو كساسين در سويههاى بالينى سالمونلا انتريتيديس

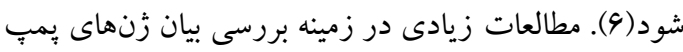
افلاكس در سويههاى سالمونلا انتريتيديس انجام گرفته

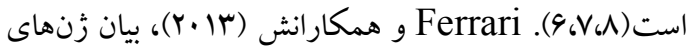

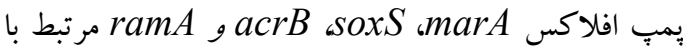
بمبٍ افلاكس AcrAB-TolC را در سويههاى سالمونل انتريكا مورد مطالعه قرار دادند. نتايج اين مطالعه نشان داد كه ركه

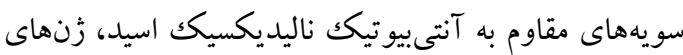

مقدمه

سالمونلا انتريكا زير گونه انتريكا سرووار انتريتيديس يكى از باكترىهاى بيمارىزاى انتقالدهنده از راه مو اد غذايى است كه اخيراً به اغلب درمانهاى كوئينولون مقاوم شده است (1). سالمونلا /نتريتيديس يكك باكترى گرم منفى بىهوازى اختيارى بوده كه به عنوان يكى از عوامل مهم ايجادكننده كاستروانتريت در نظر گرفته مىشود(1). بر طبق آمار سازمان بهداشت جهانى از سال •199، سالمونلا/نتريكا زير فتردير كونه انتريكا سروتايب/نتريتيديس به عنوان شايع ترين عامل كاستروانتريت سالمونلايى در سرتاسر جهان مطرح و و جايكزين سالمونلا تيفى موريوم گرديد(Y). بيمارىهاى ناشى از سالمونلا دركود كان و افراد بالغ و مسن شايع است ستردي و سالانه ميليونها مورد بيمارى سالمونلوز در دنيا رخ مى سـ دهد .سالمونلوز در ايران يكك بيمارى مطرح مى باشد و

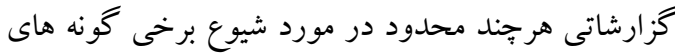
آن در كشور به ثبت رسيده است(Y). بسيارى از كشورها طغيانهاى مرتبط با جداسازى سالمونلاهاى مقاوم به جند ليد دارو را از ماكيان، دامها و خوكك گزارش كرده اند. ظهور مقاومتهاى دارويى در باكترى سالمونلا انتريتيديس هم در انسان و هم در حيوانات گزارش شده است و اين مسئله بهعنوان يكى از مشكلات سلامت عمومى محسوب مىشود. سويههاى سالمونلا انتريتيديس داراى مقاومتهاى جند كانه دارويى مشكلات عديدهاى را در درمان ايجاد كردهاند، به طورى كه يكى از دلايل مقاومتهاى آنتىبيوتيكى در اين

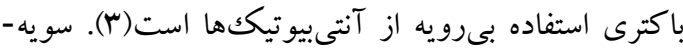
هاى مقاوم به سييروفلو كساسين از جمله مهمترين سويههاى مقاوم به آنتىبيوتيك سالمونلا انتريتيديس مىباشند كه به تدريج به تمامى آنتى بيوتيككها در حال مقاوم شدن هستند. به دنبال تجويز سييروفلو كساسين جهت درمان عفونت ناشى لئى

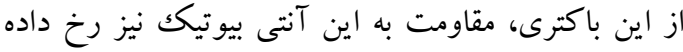

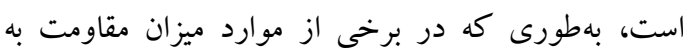
(F).... 
غنى كننده سلنيت F و محيط انتخابى XLD MAC آكاركشت داده شد. بِ از انجام آزمونهاى بيوشيميايى مورد نظر جهت جداسازى و تائيد سالمونلا بر روى جدايههاى مشكوكك (مالونات، تستهاى كالرى انتروباكترياسه MR-، Urease,lysin decarbocylase) تستهاى Simmon citrate agar، TSA، SIM،VP شده و ايزوله جداشده با ويزكىهاى بيوشيميايى: لاكتوز منفى، حركت مثبت، واكنش د كربو كسيلاسيون ليزين مثبت، سيترات مثبت، هيدروليز اوره منفى و متيل رد مثبت بهعنوان يكك ايزوله متعلق به جنس سالمونلا قلمداد مى گرديد(9). تمامى محيطهاى مورد استفاده از شركت مركك بوده است (Merck,Germany) مشخص نمودن آنتىزنهاى O O O آنتى سرم اختصاصى

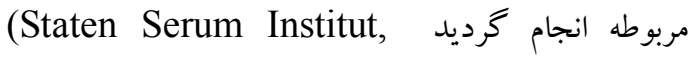
.Copenhagen, Denmark) بررسى حساسيت آنتىبيوتيكى ايزوله ها نسبت به آنتىبيو تيكها بس از شناسايى و تائيد سويههاى سالمونلا انتريتيديس،

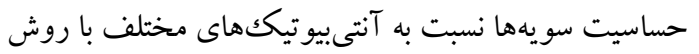

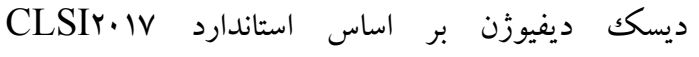
(Clinical and Laboratory Standards Institute)

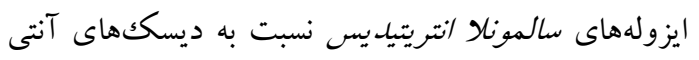

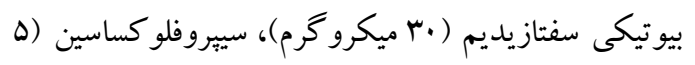

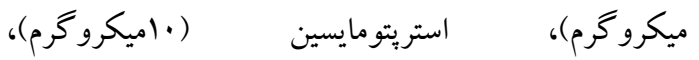
سولفومتاكسازول/تريمتويريم (ه ميكرو گرم)، تتراسايكلين

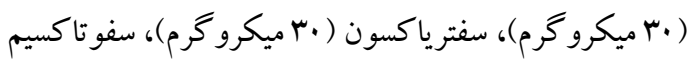

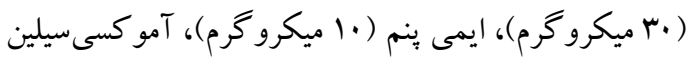

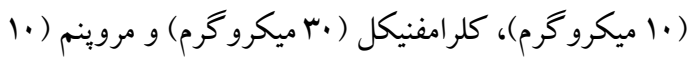

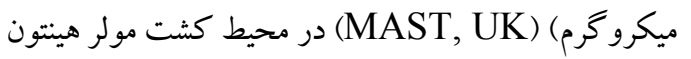

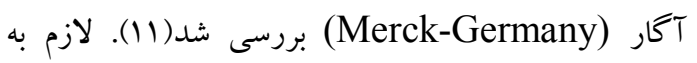
ذكر است در تمامى انجام آزمايشها، از سويه استاندارد
يمب افلاكس مرتبط با AcrAB-TolC را بيان

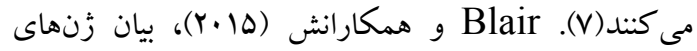
يمب افلاكس RND را مورد مطالعه قرار دادند. نتايج اين

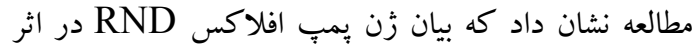

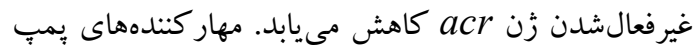

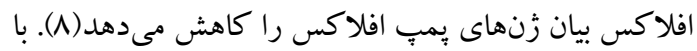
توجه به بروز مقاومتهاى دارويى در سويههاى بيمارىزاى بهاي

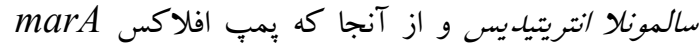
يكى از فاكتورهاى مهم در سويههاى بالينى سالمونلا

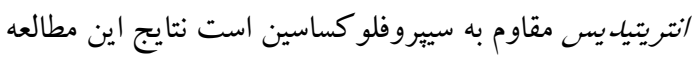
مى تو اند براى مراكز تحقيقاتى و درمانى حائز اهميت باشد و در استراتزىهاى بيشخيرى و درمان، مورد استفاده قرار

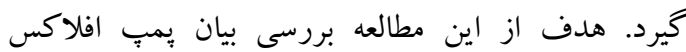
MarA

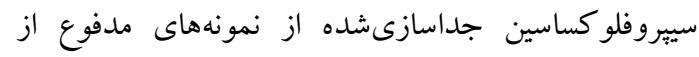
بيمارستانهاى شهر تهران است.

\section{مواد و روشها}

نمونه گيرى، كشت و تشخيص ايزولههاى باكتريايى سالمونلا

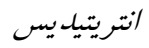
در اين مطالعه توصيفى-مقطعى، در فاصله زمانى حدوداً 4 ماه از ارديبهشتماه تا آبانماه سال هوها از تعداد .. Ir نمونه مدفوع مشكوك به سالمونلا از بيمارستانهاى امام خمينى(ره)، شريعتى و مركز طبى كودكان شهر تهران از

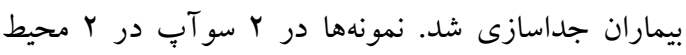
انتقالى Carry-Blair به همراه فرم خطى كه مربوط به به بهال

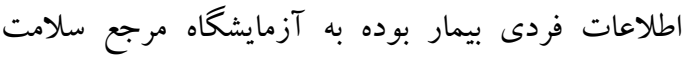
دانشكده بهداشت دانشگاه علوم بزشكى تهر ان منتقل شدند.

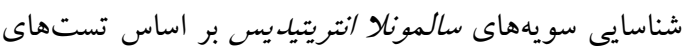
ميكروبشناسى و سرولوزيكك انجام گرفت. براى تائيد فنوتيى تشخيص جنس و گونه سالمونلا، از محيط كشت 


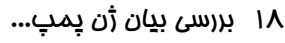

بكنواخت تشكيل شود. سبس با دور rpm ...r. ه دقيقه سانتريفيوز كرده و فاز بالايى (فاز آبى) را به لوله هاى جديد منتقل مى كنيم. اين مرحله دو بار تكرار شده و

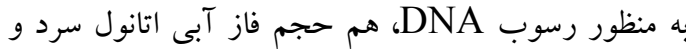
خالص به همراه // ميكروليتر استات سديم (1M) اضافه مى كنيم و آن را به مدت ب ساعت در دماى •r- درجه سانتى گراد قرار مىدهيم. بعد از آن، لوله مورد را سانتريفيوز

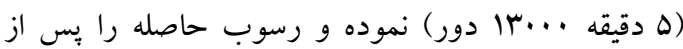
خشك كردن و حل كردن در بافر به عنوان DNA مورد استفاده قرار مىدهيم و در نهايت براى تائيد صحت استخراج زنوم از الكتروفورز زل آكاروز اء استفاده شد(זا). واكنش PCR براى زن يمب افلاكس ParA

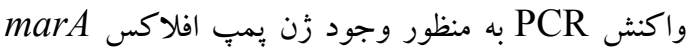
در ايزولههاى مقاوم به سيبروفلوكساسين سالمونلا انتريتيديس انجام گرفت، بهطورى كه واكنش PCR در بردام

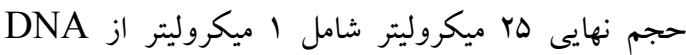

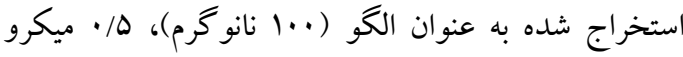

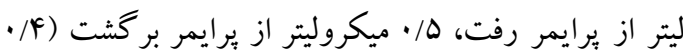

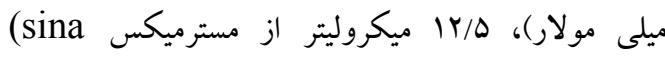
(IX)gen,iran) تقطير انجام گرفت. در ادامه واكنش PCR براى زُن

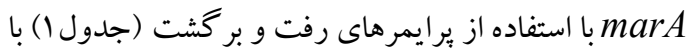
برنامه دمايى مناسب (جدول r) در طى هr سيكل انجام

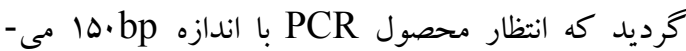

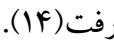

بررسى بيان زُن بِمب افلاكس marA در سويههاى بالينى سالمونلا انتريتيديس بيان زدن بيد

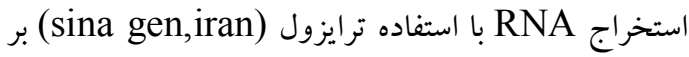
طبق دستورالعمل انجام گرفت. سبس جهت تعيين غلظت و

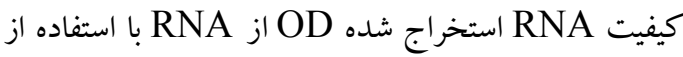

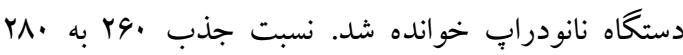
خلوص RNA را نسبت به آلودگى بروتئين نشان مىدهد
سالمونلا ATCCir.v9 از مركز ملى ذخاير زُنتيكى و زيستى ايران به عنوان كنترل مثبت مقاوم به سييروفلو كساسين ( حاوى زن (marA) استفاده شد. بررسى فنوتييى وجود يֶّب افلاكس marA با روش كارت ويل به منظور بررسى فنو تييى وجود يُمٍ افلاكس در ايزولههاى

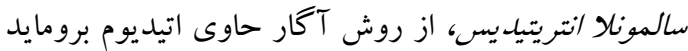

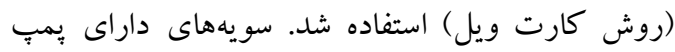
افلاكس توانيى بمٍ كردن اتيديوم برومايد به خارج از سلول را دارند؛ بنابراين در تست به رنگك تيره و آنهايى بهائ كه فاقد يمبٍ افلاكس هستند، اتيديوم برومايد به داخل سلول نفوذ كرده و فلوروسنت (روشن) مشاهده مىشوند. در ابتدا سويههاى مقاوم به سييروفلو كساسين سالمونلا

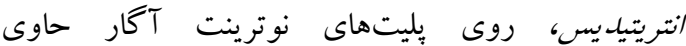
غلظتهاى متفاوت اتيديوم برومايد (از هـ/• تا ه/ ميلى

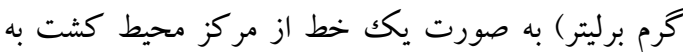

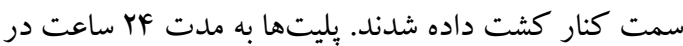
دماى WV درجه سانتى گراد انكوبه شدند و در نهايت ميزان فلورسنت هر ايزوله با استفاده از دستكاه زل داكى اندازهكيرى شد. سويههايى كه خاصيت فلورسنت ندارند، داراى يمب افلاكس بودند و سويههايى كه خاصيت فلورسنت دارند، فاقد يُمٍ افلاكس بودند (r I). DNA استخراج استخراج DNA به روش دستى (فنل كلروفرم) انجام شد. بهطور خلاصه، به رسوب تهيه شده از كشت باكترىهاى مقاوم به سييروفلو كساسين، به ترتيب ل.9 ميكروليتر بافر ليز (Tris-Hcl, pH7.4; EDTAه· mM)

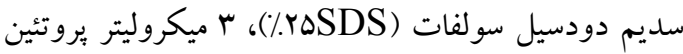

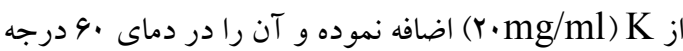
سانتى گر اد به مدت يكك ساعت قرار مىدهيم. به دنبال آن

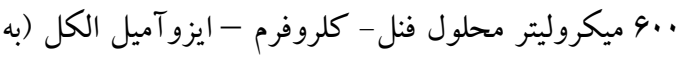

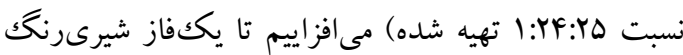




\section{$16 S \quad$ rRNA-R5'- $\quad$ g ب r}

CCGCTGGCAACAAAGGATAA-3'

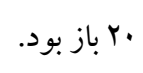

$$
\text { تجزيه و تحليل آمارى }
$$

محاسبه آمارى اين مطالعه با استفاده از نرم افزار

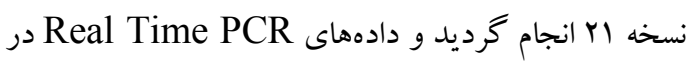
مقايسه بازن (1) S rRNA) house keeping با آناليز

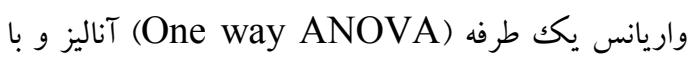

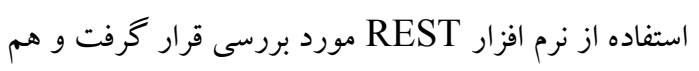
جنين ه•/P از نظر آمارى معنىدار در نظر قرار گرفته شد.
كه در محدوده Y بود. همجينين نسبت •Yq به .بr كه نشان دهنده وجود آلودگىهايى از قبيل فنل و ساير تركيبات

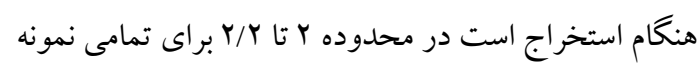

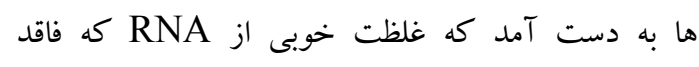
آلودگى بروتئين و مناسب براى سنتز cDNA بود به به دست

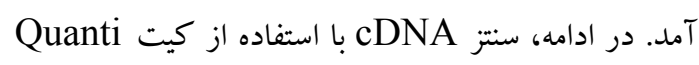
Tect Reverse Transcription kit (Takara,Japan)

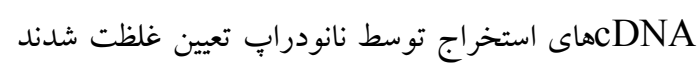

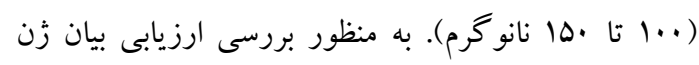

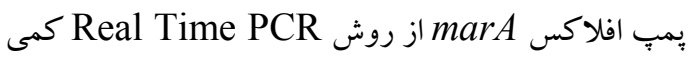
Quantitative Real-Time-PCR (qRT-PCR)

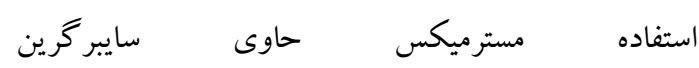
انجام كرفت. مواد مورد (Ampliqon,Denmark) استفاده در حجم نهايى ها ميكروليتر شامل ه ميكروليتر از

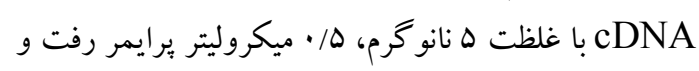

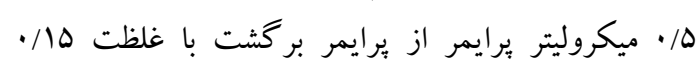

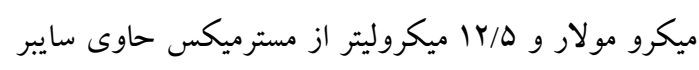

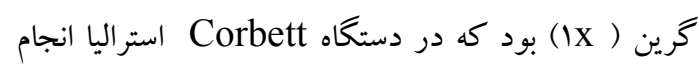

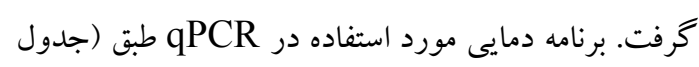

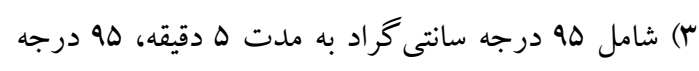

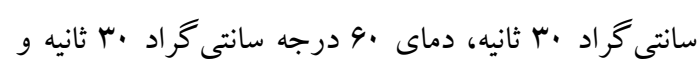

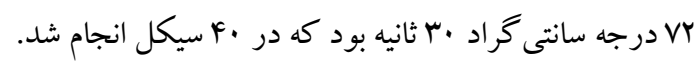

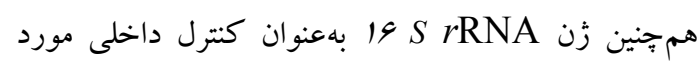
استفاده قرار كرفت(ها). در انتها بيان نسبى زن توسط روش

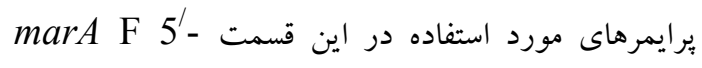
GACCCGGACGTTCAAAAACTAT -3' marAR-5' - , و ب r. با TCGCCATGCATATTGGTGAT -3' 16SrRNAF5' - و همجنين CGTGTTGTGAAATGTTGGGTTAA-3' 
جدول ا. يرايمر مورد استفاده براى زن marA

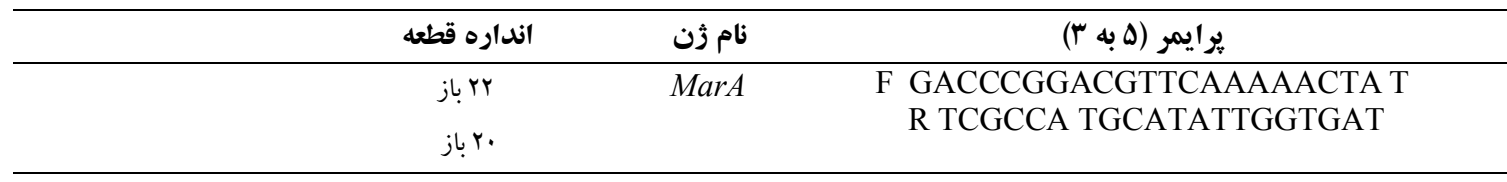

جدول r. برنامه دمايیى مورد استفاده در PCR

\begin{tabular}{|c|c|c|}
\hline 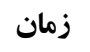 & دما (سانتى گر اد) & نام مرحله \\
\hline 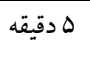 & 90 & واسرشتكى اوليه (Initial Denaturation) \\
\hline 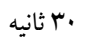 & 90 & واسرشتكى (Denaturation) \\
\hline 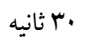 & $\Delta \Delta$ & اتصال ير ايمر ها به DNA الكو (Annealing) \\
\hline 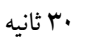 & VY & طويلشدن رشته الكو (Extension) \\
\hline
\end{tabular}

Real Time PCR جدول rا. برنامه دمايى مورد استفاده در

\begin{tabular}{|c|c|c|}
\hline زمان & دما (سانتى كر اد) & نام مرحله \\
\hline ه م دقيقه & 90 & واسرشتكى اوليه (Initial Denaturation) \\
\hline 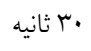 & 90 & واسرشتكى (Denaturation) \\
\hline 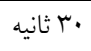 & 4. & اتصال يرايمر ها به DNA الكو (Annealing) \\
\hline 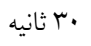 & VY & طويلشدن رشته الكو (Extension) \\
\hline
\end{tabular}

جدول f. الكوى مقاومت ميكروبى سويههاى بالينى مقاوم به سيبروفلو كساسين و حد واسط سالمونلا انتريتيليس.

\begin{tabular}{|c|c|c|c|c|c|c|c|c|c|c|c|}
\hline شماره نمونه & 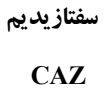 & $\begin{array}{c}\text { سفوتاكسيم } \\
\text { CTX }\end{array}$ & $\begin{array}{c}\text { استريتومايسن } \\
\text { S }\end{array}$ & $\begin{array}{c}\text { سفترياكسون } \\
\text { CRO }\end{array}$ & $\begin{array}{c}\text { تراسايكلين } \\
\text { T }\end{array}$ & $\begin{array}{c}\text { تويمتويريم } \\
\text { TS }\end{array}$ & $\begin{array}{c}\text { آموكسى سيلين } \\
\text { A }\end{array}$ & $\begin{array}{l}\text { مروينم } \\
\text { MEM }\end{array}$ & $\begin{array}{c}\text { كلر امفنيكل } \\
\text { C }\end{array}$ & ايمينم & $\begin{array}{c}\text { سييروفلوكساسين } \\
\text { CIP }\end{array}$ \\
\hline r & حساس & حساس & حساس & حساس & حساس & حساس & اسس & حساس & حساس & حساس & نيمه حساس \\
\hline$r$ & حساس & حساس & حساس & حساس & حساس & حساس & ح & حساس & حساس & حساس & نيمه حساس \\
\hline f & حساس & حساس & حساس & حساس & حساس & حساس & حساس & & حساس & حساس & نيمه حساس \\
\hline$\Delta$ & حساس & حساس & نيمه حساس & حساس & حساس & حساس & 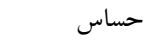 & حساس & حساس & حساس & مقاوم \\
\hline & نيمه & & & & & & & & & & \\
\hline 9 & حساس & حساس & حساس & حساس & حساس & حساس & إس & س س & حساس & حساس & نيمه حساس \\
\hline 9 & حساس & حساس & حساس & حساس & حساس & حساس & سيساس & 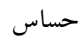 & حساس & حساس & مقاوم \\
\hline
\end{tabular}




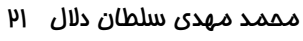

\begin{tabular}{|c|c|c|c|c|c|c|c|c|c|c|c|}
\hline ir & حساس & حساس & حساس & حساس & حساس & حساس & حساس & حساس & حساس & حساس & نيمه حساس \\
\hline if & حساس & حساس & حساس & حساس & مقاوم & مقاوم & مقاوم & حساس & حساس & حساس & نيمه حساس \\
\hline 10 & حساس & حساس & حساس & حساس & حساس & حساس & حساس & حساس & حساس & حساس & نيمه حساس \\
\hline 19 & حساس & حساس & حساس & & حساس & حساس & حساس & حساس & حس & حس & مقاوم \\
\hline 19 & & حساس & حساس & حساس & مقاوم & مقاوم & مقاوم & حساس & حساس & حساس & مقاوم \\
\hline rr & حساس & حساس & مقاوم & & مقاوم & مقاوم & حساس & حساس & & & نيمه حساس \\
\hline YA & حساس & حساس & حساس & حساس & حساس & حساس & حساس & حساس & & ح & نيمه حساس \\
\hline ו & مقاوم & مقاوم & مقاوم & مقاوم & حساس & مقاوم & مقاوم & حساس & حساس & حساس & مقاوم \\
\hline Mr & حساس & حساس & حساس & حساس & حساس & مقاوم & مقاوم & حساس & حس & ح & مقاوم \\
\hline M & حساس & حساس & حساس & حساس & حساس & حساس & حساس & حساس & حساس & حساس & نيمه حساس \\
\hline r & حساس & حساس & حساس & حساس & حساس & حساس & حساس & حساس & حساس & حساس & مقاوم \\
\hline f. & حساس & حساس & حساس & حساس & حساس & حساس & حساس & حساس & ح & & نيمه حساس \\
\hline Fi & حساس & حساس & حساس & حساس & حساس & حساس & حساس & حساس & حساس & حساس & مقاوم \\
\hline 99 & حساس & حساس & حساس & حساس & حساس & حساس & حساس & حساس & حساس & حساس & مقاوم \\
\hline
\end{tabular}


بين وجود زن marA و مقاومت به سييروفلو كساسين در بين

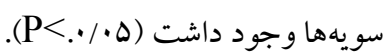

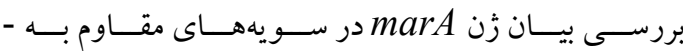
سييروفلو كساسين در سويههاى سالمونلا انتريتيديس در اين

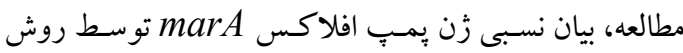
Real Time PCR قرار كرفت (شكل Y). تكثير اختصاصى قطعـات زنسى مـورد

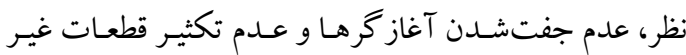
اختصاصى بـراى زن بـا استفاده از منحنى ذوب تعيـين شـــ.

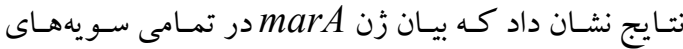

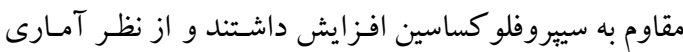

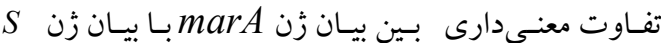

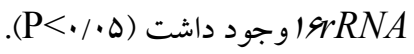

يافته ها

جداسازى و بررسى الخَّى مقاومـت ميكروبى سـويههـاى

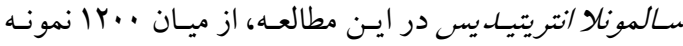
مـدفوع مشـكو كك بـه سـالمونلا، تعـداد •9 سـويه سـالمونلا

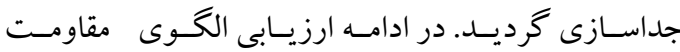

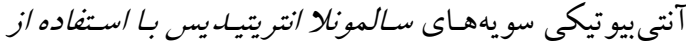
روش ديسك ديفيوزن انجام كرفت. نتايج نشان داد كـه از

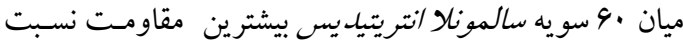

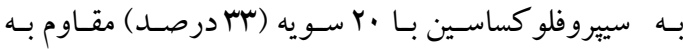
سييروفلو كساسين بودند كه 9 سويه (ها درصد) مقـاوم و 11 سويه (N| درصـد) حسد واسط (Intermediate) بودنـدو كمترين ميزان مقاومـت بـه كلر امفنيكل و ايمى بــنم (... درصد) حساس بودند (جدول r). بررسى وجود بمبٍ افلاكس توسط تست كارت ويلـدر اين مطالعه، سويههاى سالمونلا انتريتيد يس مقاوم و حـد واسط فيط بـه سييروفلو كساسين جهـت بررسى وجـود يمـب افلاكس توسط تست روش كـارت ويـل مـورد مطالعه قـرار گرفتنـد. نتايج تست كارت ويل نشان داد كه تمامى سويههـاى مقاوم

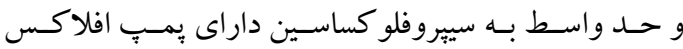
هستند، بهطورى كه سويههاى داراى بمب افلاكس،

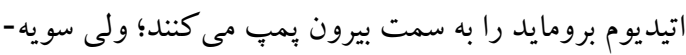

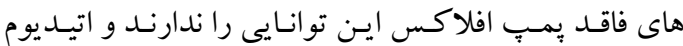
برومايد در داخـل سلول وارد مسىشود و از خـود خاصيت فلورئوسنت دارند (شكل ().

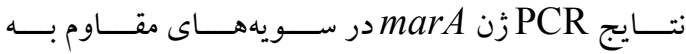
سيبروفلو كساسين به منظور بررسى وجود زن يُمـب افلاكس marA از ير ايمرهاى اختصاصى اين زن استفاده شد و انتظار وجود بانـــ •10 جفـت بـاز وجـود داشـت كـه در زل الكتروفـورز

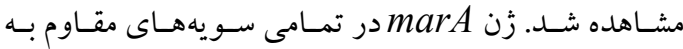
سييروفلو كساسين ديده شد ( •r نمونه) و ارتباط معنىدارى 


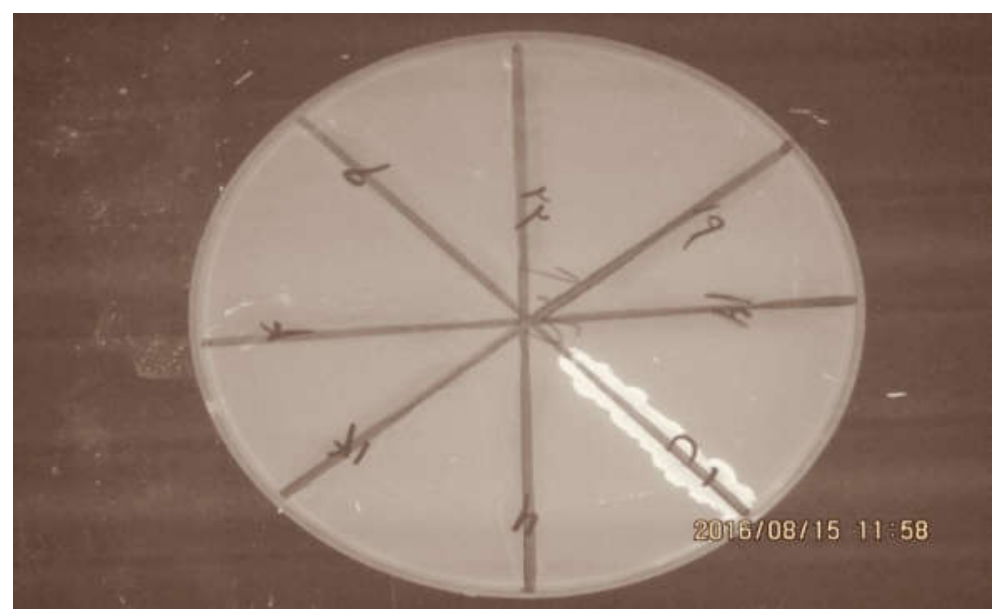

شكل 1. نتايج تست كارت ويل به منظور تعيين وجود يمبٍ افلاكس. سويههاى فاقد يُمب افلاكس فلوروسانس و سويههاى فاقد يمبٍ افلاكس فاقد فلورئوسنس مىباشند.

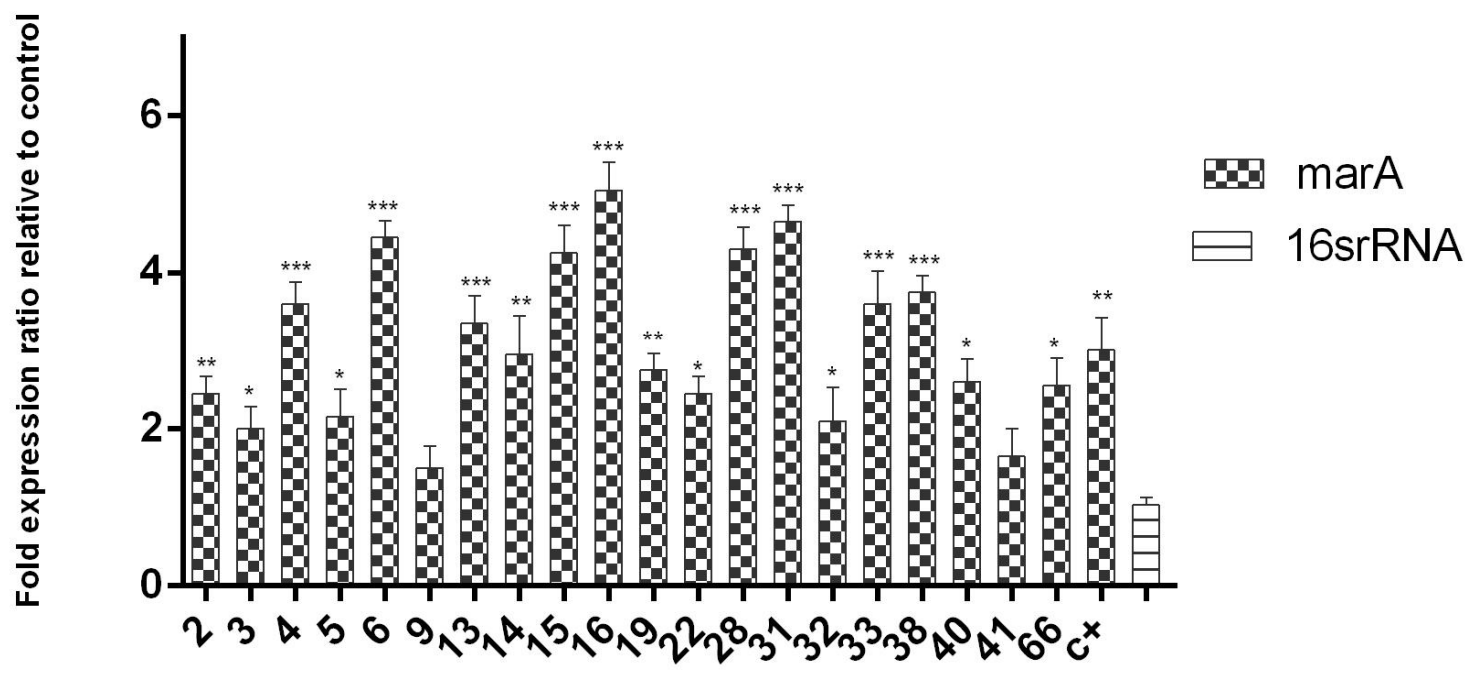

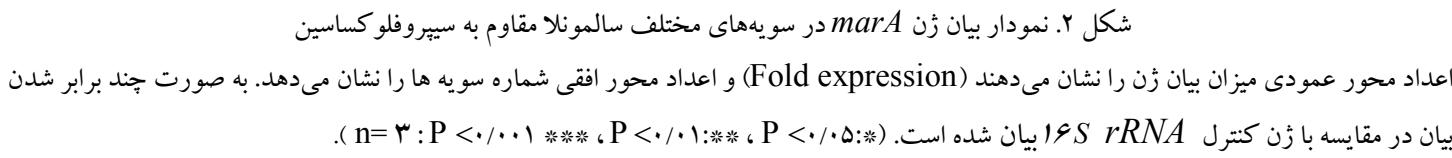


معنى مارى بين بيان زن marA با بيان زن SRA وجود داشت.

در يُزوهشى پِمب هاى افلاكس را در ها ها سويه استافيلوكوكوس اورئوس مقاوم به سييروفلو كساسين با بزائ

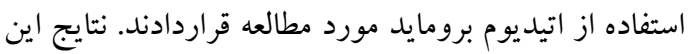

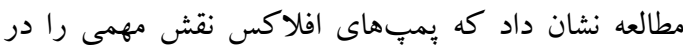
مقاومت به آنتىبيوتيككها دارد(1) ..طى تحقيقى كه روى -

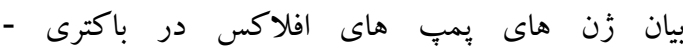
استافيلوكوكوس /ورئوس با روش وuantitative Real

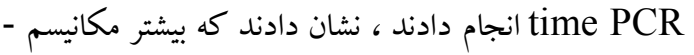
مقاومت دارويى از تغيير در بيان زن هاى بمٍِ هاى افلاكس دارويى ازجمله زن هاى يمب افلاكس norA و norB حضور آنتىبيوتيكها افزايش مىيابد كه با مطالعه ما همخوانى داشت(19). Goli

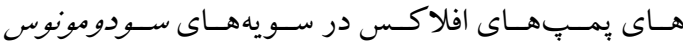

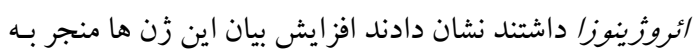

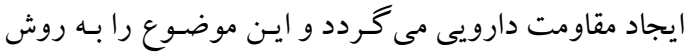
quantitative Real time PCR روش را بهترين روش جهت بررسى افزايش بيـان زن عنوان

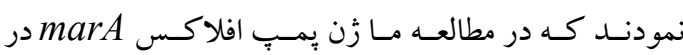
سويههاى مقاوم افزايش بيان داشته است (r). در يزوهشى ديخر در ايران با عنوان بررسى بيـان و عملكرد

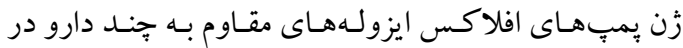
اسيتوياكتر بومانى غير كلونال به روش Real-time PCR

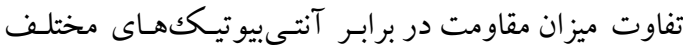

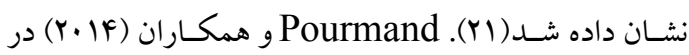
مطالعهاى وجود زُن بِمب افلاكس norA /ستافيلوكوكوس

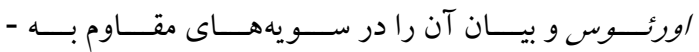

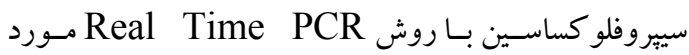

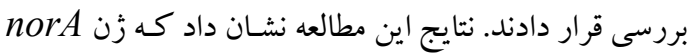

در اين مطالعه ميزان مقاومت آنتىبيوتيكى سويههاى سالمونلا انتريتيديس و هم جنين ميزان بيان زن بمبِ افلاكس marA در سويههاى مقاوم به سييروفلو كساسين مورد مطالعه قرار كرفت. نتايج اين مطالعه نشان داد كه از ميان ·9 سويه سالمونلا /نتريكا جداسازى شده، ·r سويه مقاوم به سيبروفلو كساسين بودند. با توجه به اين نتايج، درمان و كنترل عفونتهاى ناشى از اين اركانيسم امرى نغران-

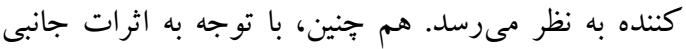
آنتىبيوتيكك ايمى ينم و مروينم، اين دارو براى درمان عفونتهاى سالمونلا مناسب نيست. مطالعات مختلف در دنيا بر روى بررسى ميزان مقاومت سويههاى سالمونلا به

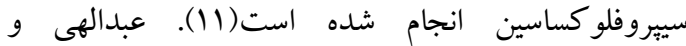
همكارانش ( •qج1)، ميزان مقاومت دارويى سالمونلا انتريكا جداسازى از نمونهاى بالينى مختلف را مورد مطالعه قرار دادند. نتايج اين مطالعه نشان داد كه هيج مقاومتى نسبت به ايمى بنم و سييروفلو كساسين وجود نداشت(19). رنجبر و همكارانش (MM (IM)، الكوى مقاومت آنتىييوتيكى سالمونل تيفى موريوم جداسازى شده از نمونهاى بالينى را مورد مطالعه نشان دادند. نتايج اين مطالعه نشان داد كه هيج كدام از لناز

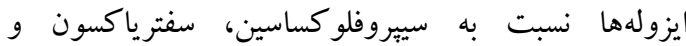
جنتامايسين مقاومتى نشان ندادند(IV). با مقايسه نتايج اين مطالعه و ساير مطالعات مىتوان به اين نتيجه رسيد كه ميزان مقاومت به سييروفلو كساسين در سويههاى سالمونلا در حال افزايش است و گزارشهاى مختلفى از ميزان مقاومت به سييروفلو كساسين وجود دارد. يكى از دلايل ميزان متفاوت مقاومت به دليل مصرف بىرويه آنتىبيوتيكها در برخى از

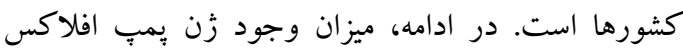
و و بيان آن در سويههاى مقاوم به سييروفلو كساسين مورد مطالعه قرار گرفت. نتايج مطالعه حاضر نشان داد كه بهان

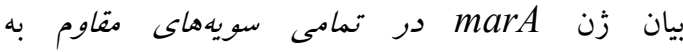
سييروفلو كساسين افزايش داشتند و از نظر آمارى تفاوت 


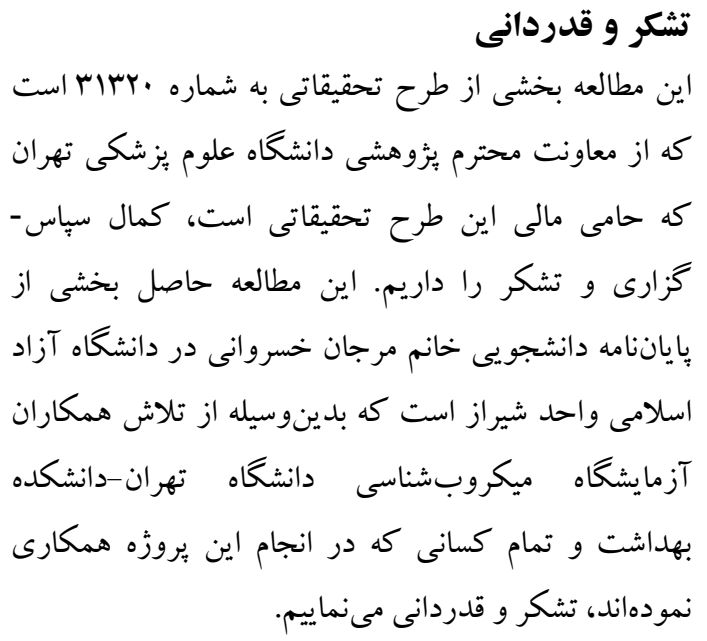

در تمامى سويه هاى مقاوم به سييروفلو كساسين وجود دارد و

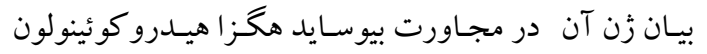

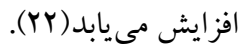

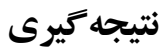

بهصورت كلى، با مقايسه نتايج مطالعه ما و ساير محققان

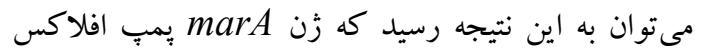
يكى از مكانيسمهاى مهم بيمارىزايى در باكترى سالمونلا

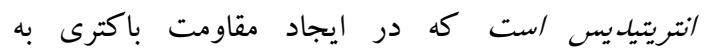

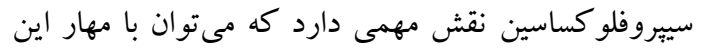
زن سبب كاهش حساسيت مقاومت آنتىبيوتيكى باكترى

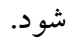

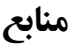

1. Sánchez-Vargas FM, Abu-El-Haija MA, Gómez-Duarte OG. Salmonella infections: an update on epidemiology, management, and prevention. Travel Med Infect Dis. 2011;9(6):263-277.

2. Ranjbar R. Naghoni A. Izadi M. Joneidi Jafari N. Panahi Y. Isolation and antibiotics resistance pattern determination of Salmonella typhimurium. Iran $\mathrm{J}$ of Public Health. 2008;11(2): 115-118.

3. Fernández J, Guerra B, Rodicio MR. Resistance to Carbapenems in NonTyphoidal Salmonella enterica Serovars from Humans, Animals and Food. Vet Sci. 2018;5(2):40.

4. Gong J, Kelly P, Wang C. Prevalence and antimicrobial resistance of Salmonella enterica Serovar Indiana in China (1984-2016). Zoonoses Public Health. 2017; 64(4):239-251.

5. Duraes FAPM, Pinto MMM, de Sousa MESP. Medicinal Chemistry Updates on Bacterial Efflux Pump Modulators. Curr Med Chem. 2018; 9:43-56.

6. Shen J, Yang B, Gu Q, Zhang G, Yang J, Xue F, et al. The Role of AcrABTolC Efflux Pump in Mediating Fluoroquinolone Resistance in Naturally Occurring Salmonella Isolates from China. Foodborne Pathog Dis. 2017;14(12):728-734.

7. Ferrari RG, Galiana A, Cremades R, Rodríguez JC, Magnani M, Tognim MC, et al. Expression of the marA, soxS, $\operatorname{acr} B$ and $\operatorname{ram} A$ genes related to the AcrAB/TolC efflux pump in Salmonella enterica strains with and without quinolone resistance-determining regions gyrA gene mutations. Braz J Infect Dis. 2013;17(2):125-130. 8. Blair JM, Buckner MM, La Ragione RM, Newcombe J, Dwyer DJ, Ivens A, et al. Beyond Antimicrobial Resistance: Evidence for a Distinct Role of the AcrD Efflux Pump in Salmonella Biology. M Bio. 2013; 22 (6): 1916-1919. 


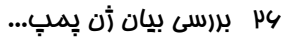

9. Busse M. Media for Salmonella. Inter J food microbial. 1995; 26(1):117-131.

10. Clinical and laboratory standards institute (CLSI), Performance standards for antimicrobial susceptibility testing; 16th informational supplement. CLSI, Wayne Pa. 2015; 10: $16-26$.

11. Stephen J, Ivonne D, Ronald J. Manual of antimicrobial susceptibility testing. ASM J. 2005;4: 616-619.

12. Martins M1, McCusker MP, Viveiros M, Couto I, Fanning S, Pagès JM, et al. A Simple Method for Assessment of MDR Bacteria for Over-Expressed Efflux Pumps. Open Microbiol J. 2013; 22(7):72-82.

13. Saremi M, Tavallaei M, Rapid genomic DNA extraction. Forensic science International: Genetics supplement series. 2008;1: 63-65.

14. Kim KY, Woo GJ. Expression of $a c r B$ and $r a m A$ in fluoroquinolone resistant mutants from multi-drug resistant Salmonella enterica serovar Haardt. Lett Appl Microbiol . 2011;52(5):484-490.

15. Furutani S, Kajiya M, Aramaki N, Kubo J. Rapid detection of Salmonella enterica in food using a compact disc-shaped device. Micromachines (Basel). 2016;7(1):10-17.

16. Abdollahi A, Najafipour S, Kouhpayeh S A, Meshkibaf M H, Naghdi M. salmonella enterica.Serotyping, Drug Resistance \& Extended Spectrum of - Lactamase (FSBLs). J fasa Univ Med Sci. 2011;1(1):38-44.

17. Ranjbar R, Naghoni A, Izadi M, Joneidi Jafari N, Panahi Y. Isolation and antibiotics resistance pattern determination of Salmonella typhimurium. Iran J Public Health. 2009;11(2): $115-118$.

18. Costa SS, Junqueira E, Palma C, Viveiros M, Melo-Cristino J, Amaral L, et al. Resistance to antimicrobials mediated by efflux pumps in Staphylococcus aureus. Antibiotics Basel. 2013; 13:2(1):83-99.

19. Dumas JL, van Delden C, Perron K, Köhler T. Analysis of antibiotic resistance gene expression in Pseudomonas aeruginosa by quantitative real-time-PCR. FEMS Microbiol Lett. 2006;254(2):217-225.

20. Goli HR, Nahaei MR, Rezaee MA, Hasani A, Kafil HS, Aghazadeh M, et al. Role of MexAB-OprM and MexXY-OprM efflux pumps and class 1 integrons in resistance to antibiotics in burn and Intensive Care Unit isolates of Pseudomonas aeruginosa. J Infect Public Health. 2018;11(3):364-372.

21. Goudarzi H, Doraghi M, Dabiri H, Ghalavand Z. Functional analysis of multidrug efflux pumps genes of Acinetobacter baumannii strains. Pejouhesh. 2013; 37 (2): 107-112.

22. Pourmand MR, Yousefi M, Salami SA, Amini M. Evaluation of expression of NorA efflux pump in ciprofloxacin resistant Staphylococcus aureus against hexahydroquinoline derivative by real-time PCR. Acta Med Iran. 2014; 52(6):424-429. 